\title{
Supersmukłe wieżowce na przykładzie realizacji z Nowego Jorku
}

\author{
Michał Dmitruk \\ https://orcid.org/0000-0002-6368-4206 \\ m.dmitruk@pollub.pl \\ Katedra Architektury, Urbanistyki i Planowania Przestrzennego, \\ Wydziat Budownictwa i Architektury, Politechnika Lubelska
}

\begin{abstract}
Streszczenie: Obserwując zmieniające się tendencje architektoniczne wysoko rozwiniętych miast, takich jak Nowy Jork, dostrzec można pojawiający się nowy trend w projektowaniu niezwykle smukłych, zaawansowanych technologicznie drapaczy chmur. Rewolucja architektoniczna rozpoczęta m.in. w Nowym Jorku na początku XX wieku, której efektem było pojawienie się pierwszych wysokościowych budynków, w latach obecnych pokazuje kolejną odsłonę. Nowopowstające budynki wysokościowe o proporcjach ołówka, trwale zmieniają sylwetę miasta. Realizacja tego typu obiektów jest wynikiem ograniczonej dostępności powierzchni budowlanej w intensywnie zurbanizowanej metropolii oraz stale rosnącego zapotrzebowania na luksusowe powierzchnie mieszkalne. Zastosowanie nowoczesnych technologii budowlanych otwiera zupełnie nowe możliwości w kreowaniu przestrzeni miejskiej.
\end{abstract}

Słowa kluczowe: architektura, budynki wysokościowe, nowoczesne konstrukcje, drapacze chmur

\section{Wprowadzenie}

Od drugiej dekady XXI wieku, zaobserwować można pojawiający się nowy trend w architekturze Nowego Jorku', polegający na wznoszeniu budynków wysokościowych, o niezwykle smukłych proporcjach. Wysokie wieżowce stanowią od wielu lat symbol Manhattanu, jednak te powstające obecnie, posiadają niespotykany we wcześniejszych latach współczynnik szerokości do wysokości, co nadaje im unikatowy wygląd. Nowojorskie Muzeum Drapaczy Chmur ${ }^{2}$ kategoryzuje budynek jako smukły, gdy jego proporcje (szerokość w stosunku do wysokości) wynoszą 1:10. Najwyższy budynek Nowego Jorku, One World Trade Center, wydaje się być smukły, lecz jego proporcje wynoszą jedynie 1:6, natomiast obiekty które stanowią temat niniejszego artykułu posiadają stosunek szerokości do wysokości, wynoszący nawet 1:24.

Niespotykany, zbliżony do ołówka kształt wieżowców, determinowany jest w głównej mierze trzema czynnikami. Pierwszy z nich, to wciąż rosnący popyt na luksusowe mieszkania, z niezwykłym widokiem na panoramę miasta. Włoskie przysłowie mówi: altezza mezza bellezza, co tłumaczyć można jako: wysokość to połowa piękna. Wysoki i smukły budynek oferuje otwarcie widokowe niemalże z każdego pomieszczenia na kondygnacji. Jak mówi Dana Getman z pracowni SHoP Architects ${ }^{3}$, budowa supersmukłych budynków, jest powrotem do ery przed pojawieniem się klimatyzacji, gdzie ważny był dostęp do światła dziennego i świeżego powietrza ${ }^{4}$. Podkreślić należy, że opisywane budynki posiadają dominującą funkcję mieszkalną, gdzie na każdej z kondygnacji znajduje się zaledwie jeden, bądź dwa lokale. Stanowią one często lokatę kapitału, oraz wykupowane są przez milionerów a także zagranicznych inwestorów. 
Kolejnym istotnym czynnikiem jest brak odpowiednich działek budowlanych w gęsto zabudowanym śródmieściu, zmuszający inwestorów do szukania sposobów do jak najefektywniejszego wykorzystania niewielkich, lecz niezwykle kosztownych parceli.

Trzecim istotnym czynnikiem, umożliwiającym powstanie obiektów o tak niezwykłym kształcie jest rozwój technologii budowlanych, zapewniających odpowiednią wytrzymałość konstrukcji, oraz specjalistycznych systemów, pomagających niwelować napory wiatru, które mogłyby spowodować chwianie się budynku, bądź jego uszkodzenie.

Jeśli popyt na supersmukłe budynki w najlepiej rozwiniętych miastach świata zostanie utrzymany, ich sylwetki mogą trwale ulec zmianie, przyjmując niespotykane dotąd, futurystyczne formy.

\section{Najważniejsze realizacje z ostatnich lat}

Pierwszy, przełomowy supersmukły wieżowiec Nowego Jorku to ukończony w 2015 roku 432 Park Avenue, zaprojektowany przez urugwajskiego architekta Rafaela Viñoly i biuro SLCE Architects, oraz biuro konstrukcyjne WSP Global. Wieżowiec wznosi się na wysokość $425,5^{5} \mathrm{~m}$ i zawiera 125 lokali mieszkalnych, ulokowanych na 84 kondygnacjach, a także liczne funkcje towarzyszące, jak np. prywatne restauracje dla rezydentów. W momencie ukończenia, był to drugi najwyższy budynek w Nowym Jorku (po One World Trade Center). Obiekt posiada prostą architekturę, składającą się z 7 dwunastokondygnacyjnych segmentów, rozdzielonych prześwitami umożliwiającymi swobodny przepływ wiatru. Każda elewacja składa się z powtarzalnego systemu kwadratowych okien, w układzie $6 \times 12$. Konstrukcja budynku oparta jest na kwadratowym, betonowym, rdzeniu $(9 \times 9 \mathrm{~m})$ o grubości ścian wynoszącej $76 \mathrm{~cm}$, a także ramie zewnętrznej, podpartej siatką kolumn o wymiarach $1,12 \times 1,12 \mathrm{~m}$. Wewnątrz rdzenia znajdują się elementy komunikacji pionowej (m.in. superszybkie, podciśnieniowe windy), oraz elementy instalacyjne budynku.

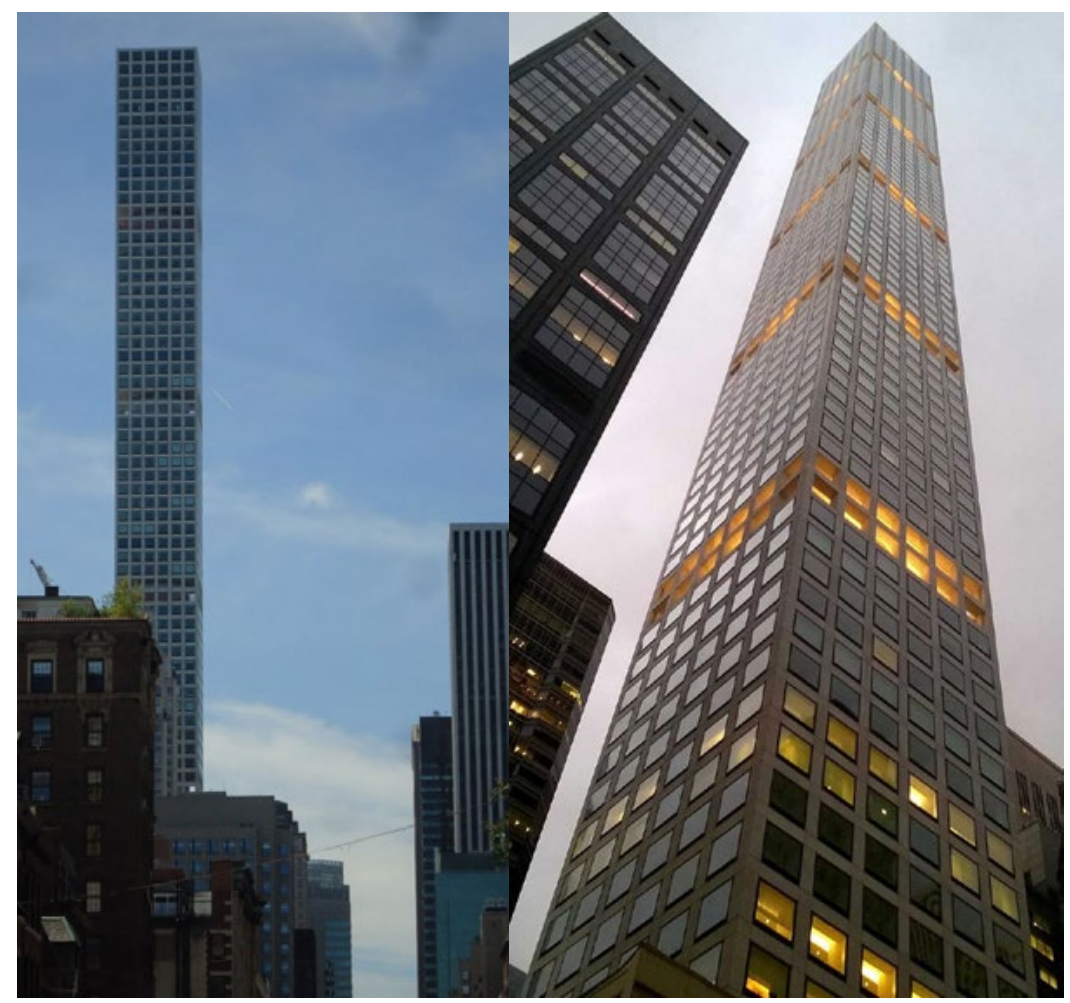

Ryc. 1. Budynek 432 Park Avenue. Źródło: wikipedia.org, na licencji CC BY-SA 4.0 
Kolejnym przykładem jest będący na ukończeniu budynek Central Park Tower, autorstwa pracowni architektonicznej Adrian Smith + Gordon Gill Architecture oraz biura konstruktorskiego WSP Global. Mierzący $472 \mathrm{~m}$ i posiadający 98 pięter obiekt, jest najwyższym na świecie budynkiem wyłącznie mieszkalnym. Zawiera 179 mieszkań, a jego koszt budowy wynosił ok. 3 miliardów dolarów. W celu uzyskania lepszych widoków na Park Centralny, wieżowiec wysuwa się zza fasady budynku 225 West $58^{\text {th }}$ Street, tworząc niesymetryczne obciążenie dla rdzenia konstrukcyjnego.

W celu zrównoważenia sił, wykonano od wschodniej strony specjalną konstrukcję, stanowiącą przeciwwagę dla budynku. Elewacja pokryta jest w całości błękitnymi panelami szklanymi stanowiącymi ścianę osłonową, co wg architektów miało pomóc wtopić się budynkowi w sylwetkę miasta ${ }^{6}$.

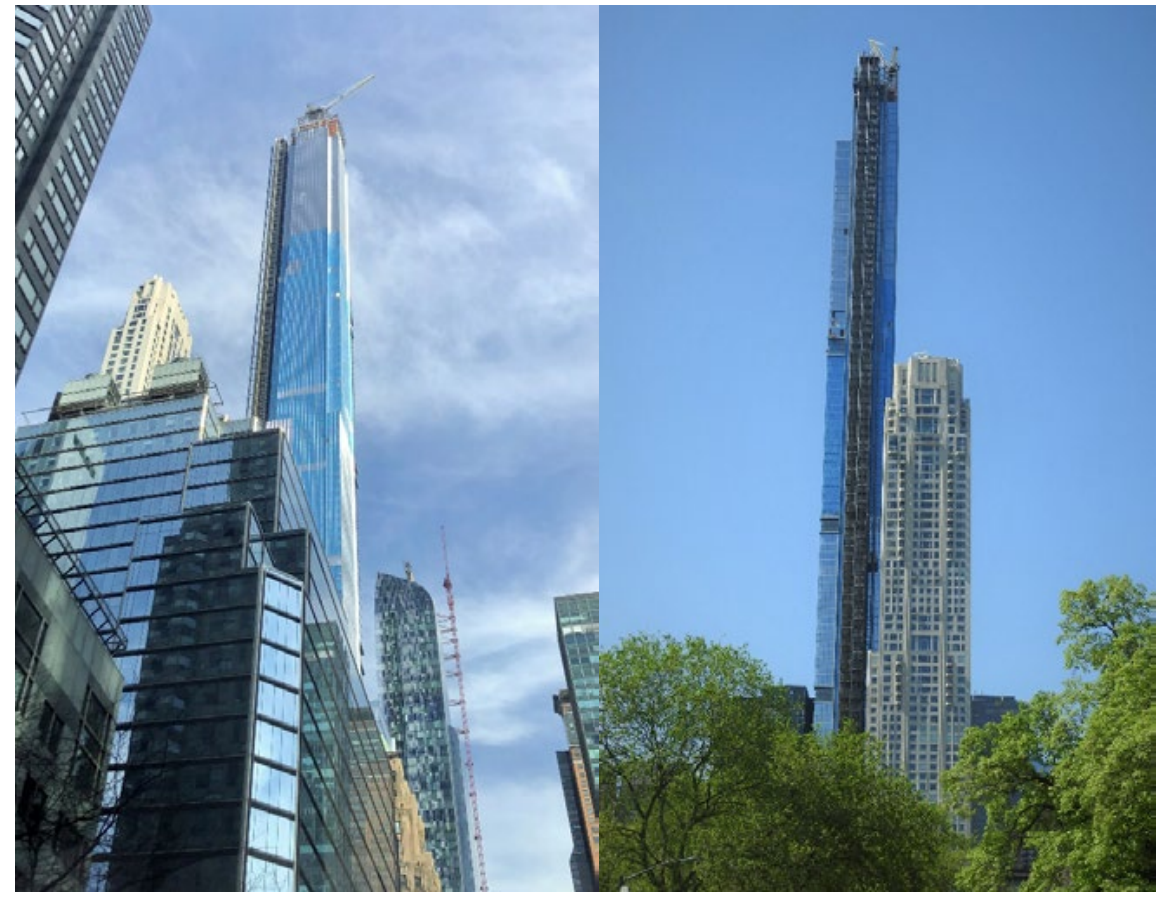

Ryc. 2. Park Tower. Źródło: wikipedia.org, na licencji CC BY-SA 4.0

Kolejnym znaczącym przykładem jest będący w realizacji wieżowiec 111 West $^{57^{\text {th }}}$ Street $^{7} .435$-cio metrowy i osiemdziesięcio-cztero kondygnacyjny wieżowiec autorstwa pracowni SHoP Architects i biura konstrukcyjnego WSP Global, jest obecnie najsmuklejszym budynkiem na świecie (stosunek smukłości około 1:24). Elewacje budynku wykonane są z lustrzanego szkła, a od strony południowej, gdzie bryła się stopniowo zwęża, znajdują się tarasy, nazywane niejednokrotnie schodami do nieba ${ }^{8}$. Konstrukcja budynku opiera się na dwóch ścianach nośnych o grubości do $91 \mathrm{~cm}$, ukrytych pod warstwami elewacyjnymi, co umożliwiało zaplanowanie komunikacji pionowej inaczej niż w poprzednich przykładach, oraz stopniowe zwężanie się szczytu budynku, wzbogacające jego formę architektoniczną. 


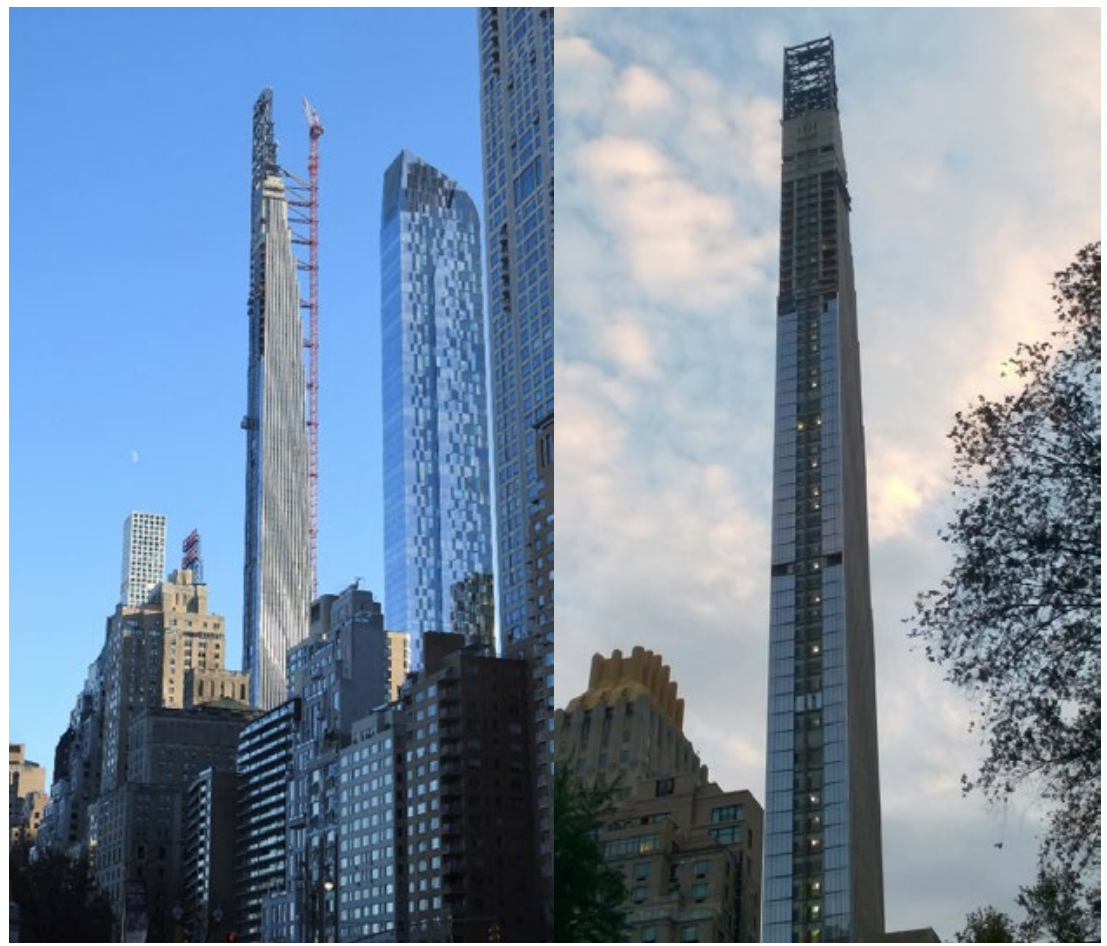

Ryc. 3. Budynek 111 West $57^{\text {th }}$ Street w trakcie konstrukcji. Źródło: wikipedia.org, na licencji CC BY-SA 4.OF

\section{Czynniki ekonomiczne}

Jeszcze do niedawna, budowa supersmukłych wieżowców była wyzwaniem na granicy opłacalności ekonomicznej, a koszty budowy przekraczały niejednokrotnie miliard dolarów?

W Nowym Jorku panowała zasada iż nie rozpoczynano budowy budynku wysokościowego, jeśli cena sprzedaży lokalu nie osiągała poziomu 32000 dolarów za 1 metr kwadratowy. Praktyka pokazała jednak, że najdroższe z apartamentów mogą sprzedać się nawet za ok. 118000 dolarów za 1 metr kwadratowy ${ }^{10}$. Właśnie z tej przyczyny, to w Nowym Jorku w tzw. Alei Miliarderów ${ }^{11}$ zapoczątkowany został nowy kierunek w kształtowaniu architektury budynków mieszkalnych w formie smukłych i wysokich drapaczy chmur. Jak pisze Artur Jasiński: Mechanizm ekonomiczny wspierający budowę nowojorskich wysokościowców oparty jest na sile popytu na luksusowe apartamenty, traktowane najczęściej nie jako miejsce do zamieszkania, lecz jako lokata kapitału ${ }^{12}$, w związku z czym sporo z nich w rzeczywistości pozostaje niezagospodarowanych.

Istotną składową wpływająca zarówno na ceny nieruchomości, jak i formę architektoniczną budynków jest dostępność odpowiednich terenów pod inwestycje. W silnie zurbanizowanym środkowym Manhattanie zwyczajnie brakuje odpowiednich działek do realizacji nowych inwestycji, co wpływa znacząco na ich ceny. Z tej przyczyny powstają coraz to wyższe budynki, wykorzystujące w jak największym stopniu przeznaczone pod nie parcele. To z kolei wiąże się z nałożeniem dodatkowej tzw. opłaty powietrznej ${ }^{13}$, wynikającej z prawa lokalnego, zabraniającego budowy zbyt wysokich budynków, w celu uniknięcia przysłaniania i nadmiernego wykorzystania przestrzeni nad parcelą. Prawa te, można wykupić jednak od właścicieli sąsiednich działek, których nie wykorzystują pełnego potencjału deweloperskiego, przez co najwyższe budynki przy Parku Centralnym zobaczyć

9 Koszt budowy wieżowca One57 wynosił około 1,5 miliarda dolarów.

10 Kwoty przeliczono ze stóp (oryg.) na metry kwadratowe. Za: Slender-Scrapers: Your Guide to the Mega High-rise Buildings of Tomorrow, 17 grudnia 2019, https://weldwide.com/high-rise-buildings-of-tomorrow/, stan na dzień 07.11.2020.

11 Billionaires' Row - nazwa nadana szeregowi ultra-luksusowych drapaczy chmur, zlokalizowanych w południowej części Parku Centralnego

12 Jasiński A., Najnowsza generacja nowojorskich budynków wysokościowych: Superwysokie, supersmukłe i... mieszkalne. Przestrzeń i Forma, nr. 28,2016, s.87

13 Air rights 
można w sąsiedztwie znacząco niższych obiektów, co dodatkowo podkreśla ich smukłość, oraz gwarantuje właścicielom nieprzysłonięty widok z okien budynku.

Prestiż staje się więc głównym czynnikiem, napędzającym realizację wspomnianych obiektów, a oferowane wyjątkowe walory widokowe stanowią o ich atrakcyjności. Skomplikowane uwarunkowania planistyczne, oraz konieczność zastosowania najnowocześniejszych technologii, wpływa z kolei na ceny oferowanych nieruchomości.

\section{Rozwiązania architektoniczne}

Konstrukcja supersmukłych wieżowców wymaga zastosowania nietypowych rozwiązań architektonicznych. Ze względu na stosunkowo niewielką powierzchnię całkowitą na każdej kondygnacji (ok. $600 \mathrm{~m}^{2}$ ), ograniczeniu musiały ulec wewnętrzne piony komunikacyjne, które w standardowo realizowanych drapaczach chmur zajmują znaczną część rdzenia budynku. Redukcja powierzchni pionów komunikacyjnych była możliwa dzięki specyficznej funkcji omawianych obiektów, gdzie każda kondygnacja stanowi odrębny lokal mieszkalny (bądź dwa) o bardzo wysokim standardzie przestrzennym. Dzięki czemu liczba użytkowników została znacząco ograniczona przez co zastosowano odrębne przepisy dotyczące dróg pożarowych, niż w przypadku budynków biurowych, o podobnej wysokości. To z kolei umożliwiło zaprojektowanie znacznie mniejszej ilości dróg komunikacji pionowej. Umieszczenie zaledwie jednego lokalu mieszkalnego na kondygnacji daje również poczucie ekskluzywności, co jest cenione przez potencjalnych nabywców, którzy mogą dostać się do własnego mieszkania, bez konieczności spotykania kogokolwiek po drodze. Zabiegiem podnoszącym dodatkowo standard przestrzenny mieszkań, jest wysoko umieszczony strop, dający wysokość brutto mieszkań na poziomie około 4,7 metra, co dodatkowo wpływa na strzelistość całego budynku.

Ważnym aspektem jest również forma elewacji budynków. Jest ona kształtowania nie jedynie fantazją architekta, ale jest odpowiedzią na silny napór wiatru na budynek. Forma budynku, jak i elementy elewacyjne testowane są w specjalnych tunelach aerodynamicznych, i profilowane w taki sposób, by odpowiednio rozbijać podmuchy wiatru, bez narażania konstrukcji na drgania, skręcanie, bądź wyginanie. Służy temu zarówno odpowiedni kształt budynku, jak i specjalny profil elewacji, pozbawiony nadmiernej ornamentyki, pomagający rozpraszać napierające powietrze. Fasady są zwykle gładkie, bez wystających elementów, mogących powodować występowanie budynku dodatkowych drgań. Elewacje najczęściej projektowane są jako ciągły system szklanych membran, które od zewnątrz tworzą atrakcyjny, nowoczesny i luksusowy wygląd, a w środku z kolei zapewniają odpowiednie doświetlenie.

\section{Zagadnienia technologiczne}

Powstanie tak wysokich i smukłych budynków nie byłoby możliwe bez zastosowania zaawansowanych rozwiązań inżynieryjnych. Znaczna wysokość, oraz niewielki przekrój poziomy struktury ${ }^{14}$, stwarzają wiele problemów natury technicznej, wymagających pilnego rozwiązania, w celu zapewnienia bezpieczeństwa konstrukcji, oraz komfortowego użytkowania przez mieszkańców.

Bardzo smukła konstrukcja musi przenosić ciężar nawet do 90 kondygnacji. Do tego celu zastosowano betonowy rdzeń konstrukcyjny, o podwyższonej wytrzymałości (do niemalże 1 tony na $\left.1 \mathrm{~cm}^{2}\right)^{15}$, do którego przymocowane są stropy międzykondygnacyjne. Sam beton trudno też nazwać tym samym materiałem, jaki był stosowany w latach poprzednich. Dzięki urozmaiconemu składowi chemicznemu, zawierającemu m.in. popioły lotne, żużel z hut, bądź mikrokrzemionkę, pozostałą z produkcji silikonów, zyskuje o wiele większą sztywność i wytrzymuje znacznie większe obciążenia. Istotne jest również posadowienie budynku. Fundamenty wspomnianych wieżowców zakotwione są w litej skale, stanowiącej podłoże wyspy Manhattan, znajdującej się na głębokości do 30 metrów poniżej powierzchni ulicy. W przypadku budynku 432 Park Avenue zastosowano 
60 kotw łączących fundamenty ze skałą macierzystą, na głębokości $-21 \mathrm{~m}^{16}$. Jednak większym problemem niż sama wytrzymałość konstrukcji na obciążenia własne, staje się napór wiatru na budynek.

Nadmierne ugięcie bądź skręcenie konstrukcji może powodować uszkodzenia struktury budynku, rozszczelnienia instalacji sanitarnych, problemy w funkcjonowaniu dźwigów osobowych czy nawet pękania paneli elewacyjnych. Ponadto, budynki mieszkalne o wysokim standardzie muszą zapewniać odpowiedni komfort użytkowania mieszkańcom, pozbawiony wszelkich drgań, przechylenia, nawet na najwyższych kondygnacjach a także nie powodując niepokojących dźwięków, jak skrzypienie elementów instalacji czy trzeszczenie murów. Budynki muszą stawiać opór wiatru nawet w najgorszych warunkach pogodowych, nie stwarzając konieczności ewakuowania mieszkańców. W tym celu wykonuje się odpowiednie testy fizycznych modeli budynków w specjalnych tunelach aerodynamicznych, badając ruch powietrza wokół struktury, obserwując jej zachowanie i odpowiednio dopasowując kształt obiektu do naporu wiatru. Jak mówi Jeff Smilow ${ }^{17}$ : Mamy mniej możliwości konstrukcyjnych, więc musimy być bardziej innowacyjni. Musimy działać z wiatrem, a nie z nim walczyć. Celem jest sprawdzenie jaki kształt budynku jest najbardziej odpowiedni ${ }^{18}$. Efektem badań jest m.in. zastosowanie w budynku 432 Park Avenue co 12 kondygnacji specjalnych prześwitów, pozwalających na zmniejszenie naporu wiatru i jego swobodniejszy przepływ. Samą formą budynku nie da się jednak zbalansować drgań wywołanych wiatrem, bądź ruchami tektonicznymi. W omawianych budynkach, na najwyższych kondygnacjach stosowana jest również specjalna poruszająca się na siłownikach przeciwwaga, reagująca na ruchy budynku i powiewy wiatru. Ma ona za zadanie balansować siły powietrza napierające na budynek, w celu powstrzymania pojawiających się drgań.

Tak złożone i skomplikowane konstrukcje wymagają współpracy wybitnych specjalistów z dziedziny aerodynamiki, budownictwa architektury i wielu innych branż. Dlatego właśnie Nowy Jork, będący symbolem nieograniczonego kapitału i rozwoju technologicznego stał się miastem sprzyjającym powstawaniu tych odważnych i przełomowych projektów architektonicznych.

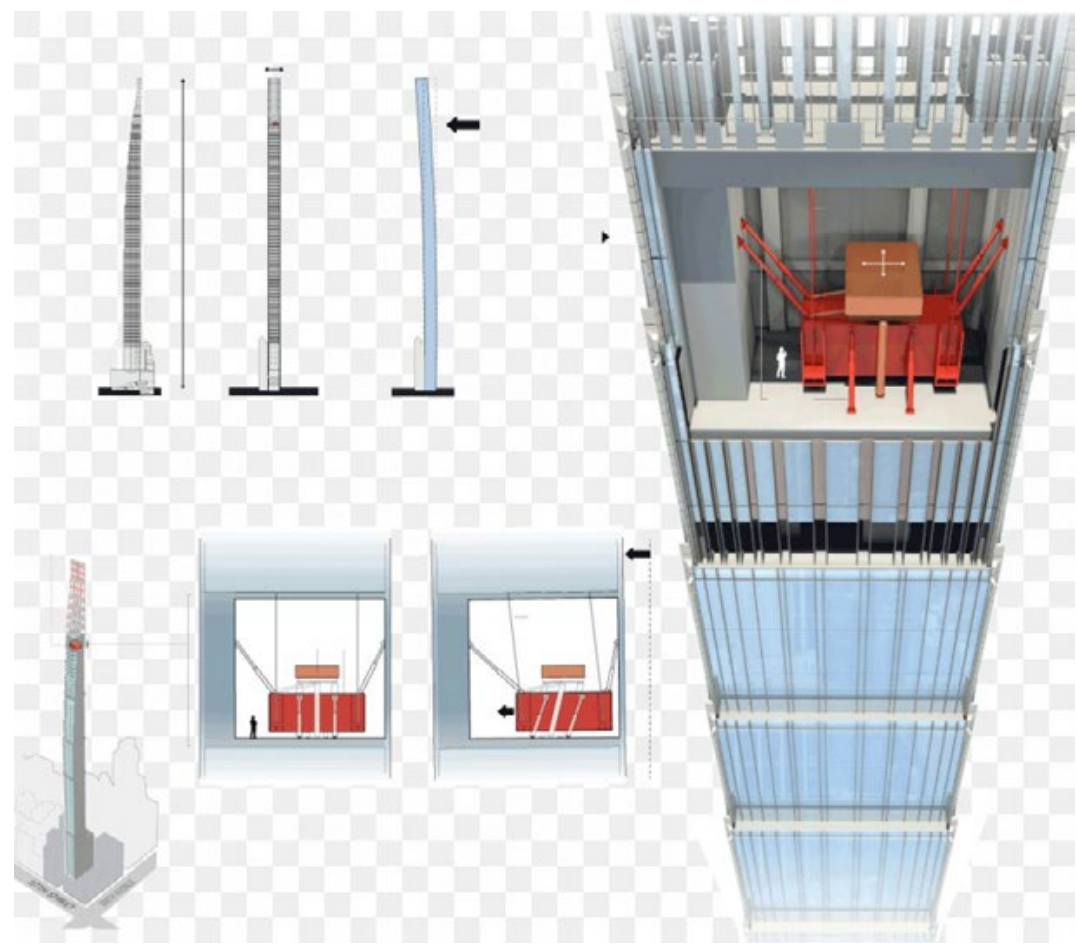

Ryc. 4. Schemat przeciwwagi, balansującej napór wiatru, w budynku 111 West $57^{\text {th }}$ Street

\footnotetext{
16 Reid R. L., Skinny 'Scrapers, [w:] American Society of Civil Engineers. 30 maja 2017.

17 Prezes firmy konstrukcyjnej Parsons Brinckerhooff w Nowym Jorku.

18 Tłumaczenie autorskie za: Super Slender Revolution, [w:] Solustions - Hight Rise Special, 09.2014, s. 14
} 


\section{Krytyka i kontrowersje}

Pojawienie się nowych odważnych przedsięwzięć architektonicznych zwykle prowokuje wiele dyskusji na temat słuszności przyjętych rozwiązań. Pierwszy z poruszanych problemów wynika ze skali i proporcji budynków. Niezwykle wysokie obiekty rzucają długi cień, często blokując światło naturalne innym budynkom. Zdaje się być to jednak problem mniejszy, w przypadku supersmukłych struktur, gdyż szersze budynki, o podobnej wysokości, jak np. One World Trade Center, rzucają znacznie większy cień. W San Francisco uchwałą miejską zablokowano realizację podobnych obiektów, wyłącznie ze względu na kwestie przesłaniania.

Kolejnym problemem związanym z niezwykłymi proporcjami budynków jest zarzut że zaburzają one naturalnie kształtująca się panoramę Manhattanu, przełamując sylwetę, wytworzoną w sposób ewolucyjny przez lata rozwoju miasta.

Pojawiają się również zarzuty natury funkcjonalnej, gdyż wielu nabywców lokali we wspomnianych obiektach traktuje je jedynie jako lokatę kapitału, nie zamieszkując w rzeczywistości apartamentów i tworząc de facto warte wiele milionów dolarów pustostany. Jest to szczególnie ważny głos w dyskusji o urbanistyce w Stanach Zjednoczonych, gdzie dużym problemem jest zjawisko eksurbanizacji, polegające na znacznym rozroście terytorialnym przedmieść. Omawiane budynki w znacznym stopniu wpływają na zwiększenie intensywności zabudowy w centrum miasta, nie zwiększając jednak stopnia zaludnienia. Uważane są również jako swoisty symbol narastających nierówności, pomiędzy warstwami amerykańskiego społeczeństwa.

Wysokie, pozbawione gzymsów i parapetów szklane budynki powodują również liczne zagrożenia, które nie były znane wcześniej. Już na etapie budowy Central Park Tower, zdarzało się iż osadzający się na szkle lód spadł z wysokości kilkuset metrów, rozpędzając się do ponad $100 \mathrm{~km} / \mathrm{h}$ i raniąc poruszających się po ulicach pieszych. Tego typu problemy muszą zostać rozwiązanie już na etapie koncepcyjnym w przyszłych realizacjach.

\section{Podsumowanie}

Wraz z rozwojem technologii budowlanej, oraz pojawieniem się precyzyjnych systemów badających siły działające na budynek, pojawiają się coraz odważniejsze projekty architektoniczne. Rozwój supersmukłych drapaczy chmur uzależniony jest od znacznych środków finansowych, dlatego pierwsze tego typu obiekty pojawiają się w najbardziej rozwiniętych metropoliach świata, jak np. Nowy Jork. Ograniczona ilość oraz ciągle rosnące ceny działek budowlanych w centrach miast, a także pęd najbogatszej części społeczeństwa do mieszkania w luksusowych rezydencjach ze wspaniałymi widokami, stają się motorem napędowym dla powstawania tego typu architektury. Można zatem spodziewać się, że dopóki istnieje popyt na supersmukłe wieżowce, to sylwetki dużych miast w najbliższych dekadach będą ulegać wyraźnym i trwałym przeobrażeniom.

\section{Bibliografia}

[1] Jasiński A., Najnowsza generacja nowojorskich budynków wysokościowych: Superwysokie, supersmukłe i... mieszkalne. Przestrzeń i Forma, nr. 28, 2016, s. 87.

[2] Mazzar, B., Inside The Supertalls: 111 West 57 $7^{\text {th }}$ Street. Bisnow. 11 Listopada, 2020.

[3] Reid R. L., Skinny 'Scrapers, [w:] American Society of Civil Engineers. 30 maja 2017.

\section{Czasopisma}

[1] Central Park Tower tops out to become the world's tallest residential building, [w:] The Architect's Newspaper. Wrzesień 2019.

[2] Return to Slender, [w:] Skylines, WSP | Parsons Brinckerhoff Publication, s. 57.

[3] Super Slender Revolution, [w:] Solustions - Hight Rise Special, 09.2014, s. 14. 


\title{
Źródła internetowe
}

[1] Slender-Scrapers: Your Guide to the Mega High-rise Buildings of Tomorrow, 17 grudnia 2019, https://weldwide.com/high-rise-buildings-of-tomorrow/, stan na dzień 07.11.2020.

[2] The most expensive wind tunnels in the world?, https://theleonardsteinbergteam.com/2014/11/the-most-expensive-wind-tunnels-in-the-world/, stan na dzień 11.11.2020.

\section{New York's superslender skyscrapers}

\begin{abstract}
Observing the changing architectural trends of highly developed cities such as New York, we can see a new emerging design trend of building ultra-slim, technologically advanced skyscrapers. The architectural revolution that started in New York at the beginning of the $20^{\text {th }}$ century, which resulted in the appearance of some of the first high-rise buildings, is now showing its latest iteration. The newly raised high-rise buildings with pencil-like proportions are permanently changing the silhouette of the city. The construction of these types of buildings is the result of limited available land in an intensely urbanized metropolis and the current development landscape encouraging the erection of luxury residential units. The use of modern construction technologies opens up completely new possibilities in creating cities.
\end{abstract}

Keywords: architecture, high-rise buildings, modern structures, skyscrapers 